\title{
Gift Appraisal Policy in Large Research Libraries
}

\begin{abstract}
In an effort to determine how extensively university libraries followed the gift appraisal policy recommended in 1961 by ACRL's Rare Books Section, a survey was made of forty-three research libraries. Responses indicate a great variation in practice, widespread dissatisfaction with practice, and differences of opinion as to the theory of appraisal. The responses are summarized.
\end{abstract}

I v 1961 the ACRL Rare Book Section submitted its "Statement of Recommended Library Policy Regarding Appraisals." ${ }^{1}$ It recommended that libraries should not appraise gifts for inheritance or tax purposes "except in those cases where only items of comparatively low monetary value are involved." The purpose of this study is to determine to what extent the recommendations have been followed by large research libraries. It was decided not to attempt a cross section of all libraries, but rather to concentrate only on large research libraries, since the latter are more often faced with the problem. ${ }^{2}$

The person accepting gifts for the li-

1 H. R. Archer, ed, Rare Book Collections (Chicago: ALA, 1965), 121. (ACRL Monograph No. 27).

${ }^{2}$ The libraries which responded to the survey were Auburn University, Brown University, University of California (Berkeley), Columbia University, Cornell University, Harvard College, University of Illinois (Urbana), Iowa State University, University of Iowa, University of Kansas, University of Kentucky, Library of Congress, Louisiana State University, University of Maryland, University of Michigan, University of Minnesota, University of Missouri, University of Notre Dame, Northwestern University, Ohio State University, University of Oklahoma, University of Pennsylvania (Philadelphia), University of Pittsburgh, Princeton University, Purdue University, Rutgers University, University of Texas, Tulane University, University of Washington, University of Wisconsin, Yale University.

Mr. Briggs is Gift and Exchange Librarian in the University of Illinois Library, Urbana, Illinois. brary should be aware of his function as a public relations agent. Any library that does not make gift appraisals must be prepared to explain its policy to friends of the library and other donors who have in the past been used to this service. Some libraries contacted during this study said that they continued to appraise books for donors who had received this service previously, but did not give estimates for first-time donors. This approach presents obvious problems.

In the course of this study forty-three research libraries were contacted; thirtytwo replied. The answers ranged from short one-paragraph letters to formal policy statements, some running to four and five pages. One library reported that its policy statement was included as a part of a routine acknowledgment form letter.

Of the thirty-two responding libraries, two were presently revising their policies and could therefore make no statement. Fifteen of the libraries make no appraisals at all, and one library has every collection appraised by a book dealer.

Three indicated that they used the ACRL Policy Statement as the policy statement for their libraries. Four of those questioned responded that they 
make appraisals for internal use only; the figures are not available to the donor.

On what do libraries base their appraisals? The Internal Revenue Service defines the value of a gift as follows: "The fair market value is the price at which the property would change hands between a willing buyer and a willing seller, neither being under any compulsion to buy or sell and both having reasonable knowledge of relevant facts. . . ." It emphasizes that the fair market value is the price the property would actually bring if presently offered for sale, not what it should bring (considering its merits). ${ }^{4}$

Of those libraries that provide donors with appraisals, two use a flat figure (excepting only volumes of obvious higher value). One library estimates $\$ 5$ per volume; the other uses $\$ 3-4$ per bound volume, \$2-3 per unbound volume, and $25 \notin$ per pamphlet.

In the remaining libraries, there seemed to be no general agreement on the basis for arriving at an estimate. Three estimated the books on the basis of their value as "used books"; one of these gave a higher evaluation to those books which were needed by the library. Four libraries estimated on the basis of replacement costs to the library, one on the basis of "current market value," and two on the basis of the original list price of the book.

Only one library cited a specific amount for serials $(25-50 \notin$ per periodical issue), although six indicated that they routinely check secondhand and reprint catalogs to determine value. It can be assumed that this would apply to serials as well as to monographic publications.

\footnotetext{
3 "Valuation for Federal Tax Purposes." Reprinted in Antiquarian Bookman, XXXIX (April 3, 1967), 1372.

"Karl Ruhe, "Valuation for Federal Tax Purposes," Antiquarian Bookman, XL (November 14, 1967), 1915-17.
}

Nor is the selection of the appraiser a matter of uniform practice. In three libraries the appraisals were made by the acquisitions librarian, in two the gift and exchange librarian, in two simply a "member of the library staff," and in one by a committee of three persons whose individual appraisals are then averaged. At the Library of Congress the Principal Evaluations Officer, in consultation with subject specialists, makes the appraisal; if the material is estimated to be worth more than $\$ 1,000$, a formal ad hoc evaluation committee, consisting of subject and acquisitions specialists, is set up. ${ }^{5}$

Many libraries indicated that there was a price limit above which they call in an outside agency to do the appraisal. There seems to be no general agreement among the libraries on this matter; each of them has a different cutoff point. Many of those who responded to the survey did not answer this question, which may indicate that they have no general policy. Listed below are the criteria used by the various libraries for calling in an outside agency to do the appraising. As no two libraries gave exactly the same standard, each of the responses below applies to only one institution.

1. Value above $\$ 20$ per item

2. Value above $\$ 100$

3. Value above $\$ 10,000$ (or containing many manuscripts or works of art)

4. Extraordinary feature about the gift

5. Average price exceeds above $\$ 3.00$ a volume

6. Rare Books

7. Gift of major importance

8. Very costly gifts

9. $\$ 500$ retention value

Ten libraries reported that they require the donor to pay for the appraisal,

\footnotetext{
${ }^{5}$ Library of Congress Regulations, LCR 315 (November 15,1966 ).
} 
five libraries pay for the service themselves, and four stated that the cost is handled by either party, depending on the circumstances.

One library reported that it appraises gifts only if it can find the items listed in a bibliographic source, such as Books in Print or Book Prices Current. Other books cited as sources for appraisal information were American Book Prices Current, British Auction Records, and PTLA. Several libraries stated or suggested that librarians were allowed to make appraisals, but not in their capacity as library staff members. Four stated that they made appraisals only after the books had been definitely given to the library.

Almost half of the libraries responding (14) suggested in some way that they were dissatisfied with their present policies. Most of them refer to the ACRL Rare Book Section statement as a goal toward which they were working, but which they were at present unable to implement. While present practice may lag well behind recommended standards, it is heartening to note that librarians are cognizant of the problems, and that they seem to be working to bring the policies of their institutions up to the recommended level.

\section{ERRATUM}

A critical and unaccountable omission occurred in our printing of Richard Berner's paper "Observations on Archivists . . ." in our last issue. The last complete sentence on p. 276 should have read: "Librarians, and archivists (by default), tend to act as if the user of manuscripts differed little in his approach to his material from the user of books and serials." 